\title{
Abrir no Mundo, Rasgando o Trecho: Mobilidade Popular, Família e Grandes Projetos de Desenvol- vimento
}

\author{
André Dumans Guedes
}

resumo A partir de uma pesquisa realizada no extremo norte do estado de Goiás, busco discutir alguns aspectos da vida de pessoas que rodam o trecho, circulando por diversas áreas do centro-norte do país em virtude do garimpo ou do trabalho itinerante para firmas ligadas a grandes projetos de desenvolvimento. Meu foco aqui reside na discussão das implicaçóes dessa forma particular de mobilidade sobre relações de cunho sexual, amoroso e familiar. Busco então extrair algumas consequências do ponto de vista nativo a respeito de tais experiências, argumentando que através delas é possível ter acesso a elementos centrais da sociologia e cosmologia do grupo em questão. Ao mesmo tempo, procuro sugerir como as práticas e ideias associadas ao trecho articulam de maneira complexa continuidades e mudanças, uma tradicional "cultura da andança" sertaneja persistindo e transformando-se diante da proliferaçáo de grandes projetos "modernos" de desenvolvimento econômico.

palavras-chave Trecho. Grandes projetos de desenvolvimento. Família. Mobilidade. Cultura popular no sertão.

O meu pai foi peão; minha mãe, solidão.

Meus irmáos perderam-se na vida à custa de aventuras...

(Renato Teixeira, "Romaria”)

Por mim, o que pensei, foi: que eu não tive pai; quer dizer isso, pois nem eu nunca soube autorizado o nome dele. Não me envergonho, por ser de escuro nascimento. Órfão de conhecença e de papéis legais, é o que a gente vê mais, nesses sertôes. Homem viaja, arrancha, passa: muda de lugar e de mulher, algum filho é o perdurado. Quem é pobre, pouco se apega, é um giro-o-giro no vago dos gerais, que nem os pássaros de rios e lagoas. O senhor vê: o Zé-Zim, o melhor meeiro meu aqui, risonho e habilidoso. Pergunto: - "ZéZim, por que é que você não cria galinhas-d'angola, como todo mundo faz?" "-Quer criar nada não..." - me deu resposta: - "Eu gosto muito de mudar..." Está aí, está com uma mocinha cabocla em casa, dois filhos dela já tem. Belo um dia, ele tora. É assim. Ninguém discrepa. Eu, tantas, mesmo digo. (Guimarães Rosa, "Grande Sertão: Veredas")

\section{Introdução}

Desde meados da década de 1980, inúmeros estudos, nos mais diversos campos disciplinares, têm se dedicado à análise dos impactos e efeitos sociais produzidos por usinas hidrelétricas no Brasil ${ }^{1}$. Na imensa maioria destes estudos, o principal tópico abordado é o chamado "deslocamento compulsório": a migração forçada de grupos situados nas áreas de instalação de tais empreendimentos. Por vários anos, eu mesmo me dediquei a trabalhar com tais questôes. E foi também em virtude disso que, em 2008, optei por realizar o trabalho de campo 
para minha tese de doutorado na cidade de Minaçu, no extremo-norte do estado de Goiás. Este município me interessava porque, nos seus limites, três barragens de considerável porte Serra da Mesa, Cana Brava e São Salvador - haviam sido construídas desde o final da década de 1980. Além disso, eu sabia que moradores da região, assessorados por militantes vindos do sul do país, haviam implantado aí uma sede local do Movimento dos Atingidos por Barragens (MAB).

Em Minaçu, porém, descobri que a maioria dos participantes deste movimento não se enquadrava no que me parecia ser então o modelo "clássico" do atingido: o pequeno agricultor que tem as terras inundadas. Ali eu estava lidando com antigos garimpeiros que haviam perdido $\mathrm{o}$ acesso aos rios e às suas margens. Além disso, com grande frequência estes últimos afirmavam para mim que a situação dramática em que se encontravam se devia também ao fato de que, após as barragens, eles não podiam mais andar: no norte de Goiás e em outras regiôes, os garimpos haviam acabado, e tudo o que lhes restava então era a vida "sedentária" e cativa de quem depende da ajuda do governo e de outras instituições para conseguir sobreviver. Eles enfrentavam então, ao contrário do que eu esperava, uma espécie de "imobilidade compulsória". Tais evidências, assim como as vicissitudes inerentes a qualquer pesquisa, me levaram então a tentar pensar de outra forma a relação entre os grandes projetos de desenvolvimento (tais quais as barragens) e a mobilidade espacial - afastando-me, assim, do tema do "deslocamento compulsório" privilegiado por aquela literatura.

Este artigo busca, portanto, explorar tal relação a partir de determinadas concepçóes e categorias nativas, tomando como referência inicial a questão da família e dela tentando extrair algumas conseqüências (cosmológicas e sociológicas) de alcance mais amplo: relativas não apenas ao universo "local" aqui considerado como também à própria natureza daqueles processos que, via noçóes como a de "desenvolvimento", nos são apresentados como particularmente emblemáticos de nossa "modernidade".

\section{A Família e o Trecho}

Aquele sábado era um dia de festa. Anderson, o filho de Regina e Altino, havia retornado de Goiânia, onde trabalhava, para passar o feriado em casa. Um tucunaré estava sendo preparado na cozinha, de três maneiras diferentes: frito, assado e no molho. Um dos adolescentes presentes disse que não suportava, nem experimentaria, peixe feito no molho. Altino, contrariado diante desse comentário, virou-se para mim e perguntou, com o rosto sério e a voz enérgica: "Onde já se viu essa mordomia? Sabe o que é isso? Sabe qual o problema desse menino? Sabe? Pois eu vou te dizer: é falta de rodar o trecho, não tenha dúvida!".

E mais uma vez eu me deparava com uma referência a esse misterioso trecho. No hotel onde eu ficava quando estava em campo abundavam as referências a esta "entidade". Os que estavam hospedados lá - representantes comerciais; gente contratada por firmas, fazendo pesquisa de minérios, instalando linhas de transmissão ou construindo subestaçóes de energia elétrica - costumavam dizer, referindo-se à situação em que se encontravam, que eles estavam correndo o trecho. Essa expressão me parecia articular-se diretamente a seus bem-humorados relatos a respeito das confusóes que arrumavam trabalhando longe de casa, sempre envolvendo mulheres e bebidas; parecia remeter também ao que, durante suas viagens, eles 
viam e viviam nos mais diversos cantos do interior do país. De certa forma, naquele dia da festa não deixava de me parecer curioso que, no seio de uma reuniáo familiar como aquela em que me encontrava, envolvendo gente de Minaçu e náo rapazes de fora, eu presenciasse mais uma menção ao trecho.

A partir de 1980, um termo curioso - o "trecho" - começa a aparecer numa série de trabalhos acadêmicos voltados para o estudo de trabalhadores "móveis" ou "itinerantes", em geral no centro-norte do país e no contexto da discussão do que seus autores vão chamar frequentemente de "grandes projetos": empreendimentos agropecuários, mineradoras, siderúrgicas, usinas hidrelétricas, obras de infraestrutura.

$\mathrm{Na}$ maior parte destes trabalhos, este termo aparece vinculado a um personagem peculiar: o "peão do trecho". No caso considerado por Esterci (1985, p. 176), estes peóes são os trabalhadores "trazidos em grandes levas" para trabalhar num projeto de colonização no nordeste do Mato Grosso, às margens do Araguaia. A autora descreve a visão depreciativa que os moradores do local nutriam a respeito desses homens estranhos que chegavam em grande número e que pareciam trazer consigo todos os signos da "desorganizaçâo social": eram "sem família”, "sem compromisso", "largados", "bêbados", "vendidos", e para atendê-los, logo, uma zona de prostituição foi instalada no local. O cenário e as representações aí presentes vão se repetir na discussão de outros autores que mencionam igualmente estes "peóes do trecho" como a mão de obra "migrante" de grandes empreendimentos agrícolas: é esse o caso dos maranhenses que vão para Mato Grosso trabalhar nas plantaçóes de soja nos dias atuais, objeto de estudo de Rumnstain (2008). Martins (1988), Figueira (2004) e Costa (2008) enfatizam as precárias condiçóes de trabalho enfrentadas por estes mesmos "peóes do trecho", vítimas por excelência do "trabalho escravo" no Mato Grosso, Pará, Bahia, Goiás, Maranhão e Piauí.

No que se refere às barragens, Magalhães (1983, p. 109), tratando do caso de Sobradinho, faz também referência ao "peão do trecho": "fundamentalmente aquele que, se deslocando de obra em obra, em locais diferentes, vive de 'trecho em trecho"'. Da mesma forma, Souza (1990, p. 26), analisando a obra de Tucuruí, menciona o "trecho" ao evocar estes mesmos peóes, trabalhadores "subcontratados (...) que por força dos vínculos contratuais e relaçóes trabalhistas se vêem obrigados a viver em condiçôes extremamente precárias seja nos alojamentos institucionais, seja na sede municipal e nos beiradóes que cotejam o canteiro e sua vila residencial".

Antonaz (1995, p. 56), estudando os trabalhadores do Projeto Albrás-Alunorte no Pará, destaca a "vivência dos projetos" como característica primordial daqueles que "correm o trecho”. Ela enfatiza assim a presença marcante de grandes projetos na vida dos trabalhadores, alguns deles nascidos e criados em vilas operárias na Amazônia em função da ocupação de seus pais. Para compreender a especificidade do que se passa com os que trabalham na Albrás-Alunorte, seria necessário assim levar em consideração "todos os grandes projetos vividos e introjetados pelos trabalhadores da fábrica (...) [seja] em Tucuruí, em Carajás, na Serra do Navio, no Jari” (Op. cit., p. 36).

$\mathrm{Na}$ sua autobiografia - sintomaticamente intitulada Urrando no Trecho. Recordaçóes de um Engenheiro de Obras - Corrêa (2007, p. 11) apresenta uma explicação para o surgimento do termo trecho:

[Este termo] vem das grandes e lineares obras de estrada onde é prática comum dividir- 
I 40 | ANDRÉ Dumans Guedes

-se o volume global de serviço em lotes, entregando-os a várias empreiteiras (...) [que ficam responsáveis por diferentes] frentes, ou trechos, da obra. É comum, num casual encontro entre operários que constroem uma mesma rodovia, a pergunta: 'Em que trecho você está?', seguindo-se a resposta que identifica a empreiteira responsável pelo mesmo e os quilômetros que limitam sua faixa de atuação. O termo Trecho extrapolou suas iniciais fronteiras e como se todo o Brasil fosse um imenso canteiro de serviços, passou a designar todas as grandes obras e os homens que as executam, os peóes do Trecho, nômades por excelência e necessidade.

O exemplo dos meus companheiros de hotel se articula assim claramente à discussão presente nesses textos, e em especial com o que afirmam Magalhães (1983), Souza (1990), Antonaz (1995) e Corrêa (2007). Em todos estes casos, o trecho se refere basicamente à experiência de trabalhadores, em geral jovens e homens, que se empregam em firmas (mineradoras, empreiteiras, hidrelétricas) para ocupaçóes temporárias longe de seus locais de origem ou moradia. A experiência dos meus companheiros de hotel, além do mais, em muito se assemelhava à daqueles que, anos antes, trabalharam na construção das barragens existentes em Minaçu. Muitos destes últimos eram também "homens do trecho", trabalhadores móveis que, após o término de uma obra, deslocavam-se para outro lugar, onde iriam construir outra usina. Ouvi muitas histórias sobre eles, na época da "febre das barragens" enxameando as ruas da cidade. Mas aqueles eram tempos passados, desde então tudo mudara. Quando estive lá, a cidade - sem o garimpo e sem as obras das barragens - estava deserta, quase abandonada. "Visite
Minaçu antes que acabe": esse comentário irônico era então comum, proferido por aqueles que, náo podendo deixar este lugar como tantos fizeram, aí foram obrigados a permanecer.

$\mathrm{Na}$ casa de Altino e Regina, porém, as coisas são um pouco diferentes. A crítica que Altino dirigiu ao adolescente que não queria experimentar o peixe ao molho pode ser diretamente contraposta ao que se passava com seu filho Anderson, um rapaz da mesma idade e que naquele dia era o centro das atençóes. Ele começara a cursar a universidade em Brasília, e sua volta para casa era o principal motivo de comemoração naquele almoço. Se aquele outro adolescente lhe parecia mimado e cheio de mordomias, esse certamente não era o caso de Anderson. Naquele mesmo dia, Regina regozijava-se ao lembrar-se de todas aquelas pessoas que haviam dito, maldosamente, que ele iria se perder no trecho, jovem como era e sujeito a tentaçóes de toda ordem. Quem falava aquilo ou sugeria que ele iria sumir no mundo - acrescentava ela -, náo podia conhecer seu menino, já tão sério e responsável aos 17 anos de idade. Uma vizinha presente à festa também estava de volta à cidade no feriado, ela que saíra de Minaçu para trabalhar como cozinheira em Goiânia. Emotiva após algumas cervejas, ela comentava sobre o quanto estava sofrendo na capital, pela vida dura que lá levava e pelas saudades que sentia. Saudades dos seus filhos e seus pais, que ficaram para trás; e também dos bons tempos do garimpo, antes das barragens, quando havia serviço e dinheiro e seus amigos ainda moravam todos por lá. Procurando consolar-se, volta e meia ela repetia, mais para si própria do que para os presentes: "Fiz sim a coisa certa, tinha mesmo que partir. Além disso, o trecho ensina, e eu preciso disso. Sim, o trecho ensina...”.

Estes dois contextos aparentemente distintos - a estadia temporária de trabalhadores 
itinerantes em Minaçu, o evento na casa de Regina e Altino - remetem aos dois "universos" que, na sua relação, serão considerados neste texto: o trecho e a familia. Prossigamos então tratando desta mesma família, evocando em primeiro lugar a situação da irmá mais nova de Altino e do marido dela - um rapaz que corre $o$ trecho trabalhando como tratorista. Elenita e Douglas são seus nomes. Após isso, e antes de concluir, retorno ao caso de Altino e Regina, para voltar a discutir alguns elementos da relação de ambos com Anderson, seu filho.

\section{Vida e trabalho no trecho}

Montado a cavalo, cortando o estradão IAssim é a vida que leva um peão, Não tenho morada, não tenho rincão / E não tenho dona no meu coração (...)

Em toda cidade por onde passei / Uma moreninha eu sempre deixei

(Tonico e Tinoco, “Cortando o Estradão”)

Ao final daquela festa, Elenita, a irmã de Altino, se aproxima de mim. Senta-se no chão, suspira. Sei que ela está triste - já há alguns dias vem parecendo abatida - e quer conversar. Ela tem tanto sonhos, e queria tanto poder realizá -los... Mas para isso teria que sair dali. Como conseguir alguma coisa naquela cidade? E sair ela não pode, não agora, não tão cedo. Algum dia conseguirá? Com duas crianças pequenas e mais uma a caminho, não lhe restam muitas alternativas. Tem que ficar e tomar conta delas, não tem jeito. Mas que vontade de ir embora! $\mathrm{Se}$ as coisas tivessem acontecido de outro modo, a esta altura ela poderia estar longe. Na Suíça, na Espanha, quem sabe? Não era lá que estavam tantas de suas conhecidas, de suas antigas vizinhas e amigas de infância? Mas ela se envolvera com Douglas, se apaixonara, engravidara, agora estava nas mãos dele. Alguns meses atrás, ela até se achava esperançosa. $\mathrm{O}$ marido largara o emprego para passar um mês com a família em Minaçu. Ele tentou então, de novo, arrumar um emprego na mineradora instalada na cidade. Fez a prova, mas não passou. Como seria bom se ele tivesse conseguido! Eles então morariam juntos, no mesmo local. Ela poderia então ter finalmente sua casa... Mesmo que eles começassem com um barraco, estava ótimo: seria a casa dela, e ela não moraria mais com os pais. E ela e as crianças teriam direito ao plano de saúde, receberiam a cesta básica, poderiam freqüentar o clube da empresa. O clube da empresa! Quem diria, ela, lá dentro da vila da mineradora, indo para a piscina como iam as mulheres dos engenheiros... E o mais importante, o marido estaria ali, ao seu lado. Tudo isso, porém, não passara de um sonho. No início do ano o marido voltaria para aquela vida que tanto parecia lhe agradar, um tempo trabalhando aqui, outro acolá, sempre mudando de firma e de cidade. Essa vida podia agradá-lo. Mas para ela, Elenita, só trazia sofrimento. O que ele estaria aprontando longe de casa? Só de pensar nas outras mulheres ela... Pois o que ia acontecer agora era isso: ele arrumaria um emprego em outro lugar e eventualmente apareceria, deixando um pouco de dinheiro. E ela continuaria ali, morando com os pais, sofrendo, esperando sabe-se lá o quê, levando aquela mesma vida...

Às constantes reclamaçóes a respeito da ausência de emprego após a construção das barragens e ao fim do garimpo, mais do que freqüentes entre aqueles com que convivi no MAB de Minaçu, é preciso contrapor outro tipo de formulação: aquela característica de 
jovens rapazes (como é o caso de Douglas, marido de Elenita) que afirmam que, para eles, trabalho não falta. Estes últimos costumam ter entre vinte e trinta e poucos anos, e em sua maioria possuem uma profissão. São, dentre outras possibilidades, motoristas, armadores, tratoristas, operadores de sonda ou de máquinas pesadas, mecânicos, eletricistas ou técnicos em mineração. Trabalham geralmente para grandes mineradoras, ou para empresas contratadas por elas; na construção de barragens; ou então para empreiteiras de todo tipo e tamanho. Com bastante freqüência, mudam de ramo, deixando, por exemplo, um emprego numa barragem para trabalhar em uma cooperativa que presta serviços para uma mineradora.

Note-se que as barragens onde eles trabalham não são aquelas que "atingiram" Minaçu, todas já prontas, mas empreendimentos em outras regióes. Conheci pessoas que trabalham ou trabalharam em usinas construídas não muito longe dali, no mesmo Rio Tocantins que banha aquela cidade, nos projetos de Peixe e Lajeado; em usinas no sul do estado de Goiás, ou em São Paulo, Minas Gerais, Mato Grosso, Rondônia, Santa Catarina e Rio Grande do Sul; e até mesmo no exterior, geralmente em Angola.

$\mathrm{Na}$ cidade de Minaçu existe ainda uma grande mineradora. Entretanto, também em função da dificuldade de obter uma vaga nesta empresa, estes rapazes costumam arrumar empregos, geralmente por pouco tempo, em mineradoras de outros municípios do norte de Goiás (regiâa conhecida pela diversidade e riqueza dos minérios aí presentes, e na qual a exploração mineral passa por um momento de grande expansão): Niquelândia, Barro Alto, Crixás, Alto Horizonte; ou ainda em estados vizinhos, sobretudo na Bahia, Tocantins e Minas Gerais.
Em Minaçu, como em diversos outros cantos desse país, é comum encontrar mulheres avaliando seus maridos em função da quantidade de dinheiro que eles colocam dentro de casa. Ao que me parece, essa não deixa de ser uma boa maneira de avaliar o grau de comprometimento de um homem com sua esposa, seus filhos, sua casa. Para a mulher cujo marido se encontra no trecho, porém, este tipo de avaliação envolve algumas especificidades. Em primeiro lugar, é difícil para ela saber se o marido foi efetivamente contratado, já que ele pode mentir com o objetivo de retardar o início das remessas - assim como pode mentir a respeito do quanto está ganhando. Em segundo lugar, a distância torna ainda mais árduos os esforços dessa mulher para canalizar uma parte significativa do salário do marido para a casa. Nesse sentido, sua preocupação é a de que estes recursos sejam dissipados com aquilo que, do ponto de vista masculino, são atrativos e tentaçóes da "vida no trecho". Essas mesmas coisas, para elas, além de consumir uma parcela do salário que poderia ter sido alocada à casa ou à família, são também perigos que sinalizam o risco de perder seu marido ou de que ele se perca. Náo deixa de ser complexa a situaçáo em que se encontram estas moças: o bom marido é aquele que tem trabalho, que é capaz de sustentar uma casa; no contexto de que trato, estes últimos, com grande freqüência, serão homens que correm o trecho. A ambigüidade aí presente fica evidente no dito jocoso que se repetia pela cidade: "A situação aqui em Minaçu está tão ruim que são as mulheres que estão enxotando os homens de casa, para ver se eles arrumam algum dinheiro no mundo...".

Para alguns desses homens, porém, essa situação não é necessariamente ruim. Afinal de contas, a vida no trecho não reserva surpresas e 
possibilidades? Não é assim, rasgando o trecho, que se conhece o mundo, que aventuras e emoções as mais diversas são vividas? Só no trecho - dizem - é possível transar com uma japonesa; ver helicópteros transportando tratores ou avióes atirando na mata bujóes de gás; encontrar uma pessoa que come com o pé, ou uma gangue de marginais liderada por alguém sem as duas pernas; no trecho é possível enriquecer da noite para o dia...

Para além destes eventos excepcionais, o trecho é, para aqueles que como Douglas têm um emprego e dinheiro para gastar, o espaço de constituição de certo tipo de sociabilidade masculina e viril, juvenil em certos aspectos. Para Elenita, seu marido "faz tudo" pelos colegas - e, conseqüentemente, menos do que deveria por ela e pelos filhos de ambos. Constituindo, viabilizando e contribuindo para a tessitura dessas relaçóes de camaradagem masculinas, três elementos principais podem ser destacados: os veículos, a bebida e as mulheres. Mais do que qualquer coisa, as farras ilustram bem como esses elementos se articulam a estas relações, constituindo algo como situações-limites, pelos excessos aí envolvidos e pelo valor que lhes é concedido.

Como é de se esperar, situações como essas assumem sentidos diversos e opostos para uns e outros. Por um lado, há a sua valoração positiva, por parte daqueles que se envolvem nessas farras e que as evocam como grandes acontecimentos e pontos altos da "vida no trecho". Por outro, há a preocupação e o temor com o que pode surgir daí: pois o que é especialmente desejado por estes rapazes é também o que causa apreensão nas suas esposas. Os riscos e perigos percebidos por elas são de diversas ordens: o gasto excessivo de dinheiro que poderia estar sendo canalizado para elas e para a casa, como já mencionado; a presença de outras mulheres (e também o medo de que uma destas engravi- de ou constitua com seu marido outra "casa", que rivalizará com a da esposa no que se refere à atenção e aos recursos dele); a possibilidade de acidentes e brigas, em virtude das combinações explosivas de álcool, direção, mulheres, valentia e testosterona; ou o medo de que ele tome o gosto por essa vida e deixe-a com os filhos para trás.

A esse respeito, o relato de um incidente relativamente trivial interessa não só por envolver numa mesma trama os três elementos acima mencionados - os vetores ou catalisadores da sociabilidade masculina de que estou tratando - mas também por evidenciar um tipo particular de transação bastante característico deste tipo de relação, onde o desperdício e a destruição de bens valiosos parecem conferir prestígio ou status. Bebendo cerveja com alguns desses rapazes que rodam o trecho, presenciei um deles sendo alvo de gozaçóes diversas. Explicaram-me então o que havia acontecido com ele. Dirigindo seu carro numa outra cidade do interior do estado, uma mulher, sozinha e também ao volante, chamou sua atenção. Ele aproximou seu veículo do dela e, pela janela, atirou o aparelho de celular que trazia consigo dentro do carro dela. Fez então um sinal com a mão, avisando-a de que sua atitude se justificava pela sua intenção de chamá-la mais tarde, ligando para o celular que ele havia arremessado. Não fora ele quem inventara aquela estratégia de paquera, fiquei logo sabendo. Outros jovens na mesa já haviam feito a mesma coisa. Se o primeiro rapaz estava sendo ridicularizado, porém, era porque, estando embriagado quando avistara a mulher, não se dera conta de que o telefone celular estava sem bateria. Mesmo que ela se dispusesse a atender sua chamada, não teria como fazê-lo. Para completar, o aparelho em questáo era um modelo particularmente sofisticado e caro (e o dono, alguém que passava por dificuldades financeiras): razão adicional 
I 44 | ANDrÉ Dumans Guedes

para que sua abordagem mal sucedida fosse ainda mais ridicularizada.

Parece-me que não estamos aqui muito longe das formas de consumação ritual de riqueza imortalizadas por Mauss (1974, p. 100): o potlatch, e mais especificamente o que este autor chama de "potlatch de destruição", com a ênfase recaindo mais sobre o aspecto da "honra" do que o do "crédito". Nesse sentido, parece-me necessário comparar e articular as farras discutidas aqui com algumas das práticas até pouco tempo atrás bastante comuns em Minaçu. Refiro-me em especial ao "fechar cabaret" tão difundido entre os garimpeiros - muitos deles pais e conhecidos destes jovens. Mesmo sendo crianças nestas épocas, diversos deles travaram conhecimento e se impressionaram com essas práticas, como se pode depreender de seus próprios relatos. Nestes dois contextos distintos, o mundo do garimpo e o do trabalho para as grandes firmas, os mesmos elementos acima destacados - a consumação ritual da riqueza à lá potlatch, as mulheres, a bebida, os veículos - se fazem igualmente presentes, mas constituindo agenciamentos distintos.

Esta comparação me parece interessante para pensar também o estatuto do consumo junto a estes jovens (e a outros "migrantes" de uma forma mais geral) que se defrontam com o "mundo das mercadorias" e suas tentações. Martins (1988, p. 6), por exemplo, afirma que "a fala do migrante [sazonal, tal qual o peáo do trecho] é, quase sempre, dominada pela lógica da mercadoria e do dinheiro, da quantidade, e recoberta pelo fascínio do maravilhoso e ilimitado das coisas que podem ser compradas e vendidas", vocabulário e lógicas "que não pertencem ao trabalhador e sim àqueles que o dominam e exploram”. Estas colocaçôes me parecem problemáticas não só por negarem aos sujeitos em questão algo que eles mesmos afirmam lhes ser próprio, negando a legitimidade de seu ponto de vista e denunciando a alienação ou ignorância que os marca. Mas também por destituírem as práticas e valores em questão de sua singularidade em prol de uma formulação genérica (e por isso mesmo banal), reduzindo-as a meros reflexos automáticos de uma lógica mercantil que se faz presente independentemente de qualquer referência a práticas e contextos concretos. Parece-me que a consideração do caso do garimpo permite ao menos que seja colocada a questão de como essas mercadorias são consumidas, e de qual o significado do seu consumo para estes jovens, que não vivem (mais) a realidade deste garimpo. Ainda no que se refere a esse ponto, na obra de Buarque de Holanda (1994, pp. 152-4) há alguns elementos particularmente sugestivos. Tratando do caso dos "tropeiros" do final do século XVII, esse autor argumenta que faltava aos primeiros "o ascetismo racionalizante" que caracteriza o ideal burguês. Isto porque estes "homens rústicos" seriam conhecidos por um "amor ao luxo e aos prazeres" evidenciado pelo gasto de todos os seus recursos em cabarés, jogos, teatros - e também no adorno dos acessórios de suas cavalgaduras com metais preciosos. Este último elemento sugere também como, tanto neste caso como naquele que estou discutindo, os veículos em questão (carros ou cavalos) são objeto de investimentos que parecem sugerir não apenas o quanto eles são valorizados mas como também o é aquilo que eles possibilitam: a própria mobilidade.

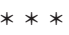

Este homem que trabalha longe de casa sabe, porém, que corre o risco de provar de seu próprio veneno. Se por um lado a distância de sua esposa e de sua família lhe concede uma liberdade que facilita o envolvimento com outras mulheres, por outro esta mesma distância 
lhe dificulta o exercício do controle e da vigilância sobre sua própria mulher.

Assassinato cruel em Minaçu Oeste, o episódio circula de boca em boca (mas sem causar maior comoção ou entusiasmo), o que foi mesmo que aconteceu? Um barrageiro - um homem que estava trabalhando fora da cidade há meses, na obra de uma barragem - fora alertado por um desses caguetes que, na sua ausência, sua mulher vinha recebendo visitas de um pé de pano. Este último merece este nome pelo silêncio e descrição com que supostamente se movimenta, se não pretende ser descoberto. $\mathrm{O}$ barrageiro chegou em casa sem avisar, e encontrou os dois na cama. $\mathrm{O}$ pé de pano conseguiu fugir, mas a mulher foi morta a tiros e seu marido preso. Não sei maiores detalhes sobre o pé de pano em questão. Ele poderia ser um vizinho, um conhecido, alguém que morasse na cidade. Ou então alguém de fora, alguém que estivesse no trecho, temporariamente em Minaçu. Afinal de contas, é preciso levar em consideração, em cidades como esta, as devidas perspectivas: o que é a "casa" de uma pessoa (neste caso, a do barrageiro) pode ser o trecho para outra - e vice-versa, naturalmente.

Além do mais, os homens do trecho costumam ser pés de pano especialmente perigosos. $\mathrm{E}$ isso porque, à leveza e discrição característica dos movimentos destes últimos, se associam os atributos e potencialidades dos primeiros: a própria transitoriedade de sua situação nesta ou naquela cidade; a liberdade de que usufruem numa terra onde conhecem pouca gente ou ninguém; a sua própria disposição para nestas circunstâncias envolverem-se em relaçóes efêmeras e nelas despenderem recursos (quase sempre superiores aos que dispóem os "locais").

Um conhecido, ressentido e preocupado, costumava me contar sobre as dificuldades por que passaram ele e seus amigos quando da construção da Usina de São Salvador, obra cujo canteiro se localizou numa cidade vizinha a Minaçu, Palmeirópolis: "Veja só, eu sou atingido pelas barragens sim. Desde que começaram as obras dessa coisa eu não consigo mais arrumar mulher aqui neste lugar! Chegou essa quantidade imensa de homens de fora, com dinheiro e de carros novos, como é que eu posso concorrer com essa gente?”. Além disso, há também, segundo ele, as mulheres que "dão para um peão qualquer”, moças simples, que sonham conseguir uma vidinha melhor com um marido que disponha de um salário fixo, e que se deixam encantar com qualquer presente bobo. São umas pobres coitadas, garante-nos ele. Que futuro elas têm engravidando de um homem desses? Depois que estas obras acabaram, Palmeirópolis ficou parada novamente. Os barrageiros todos foram embora, mas deixaram para trás muitos barraginhos: justamente os filhos que fizeram com as moças de lá.

Aparecida, uma vizinha de Elenita, sabe muito bem dos perigos de se envolver com esse tipo de homem; também porque sentiu na pele o que é ser enganada por um deles. Durante a construção da Usina Hidrelétrica de Serra da Mesa, ela envolveu-se com um baiano que viera trabalhar aí. $\mathrm{O}$ relacionamento entre eles durou mais de um ano. Nas folgas de que dispunha, ele vinha ficar na casa dela; eventualmente, voltava para sua terra natal, para, segundo ele, ir ver seus pais idosos. Suspeitando dessas viagens, Aparecida procurou saber um pouco mais sobre a vida dele, e descobriu que ele já era casado. Mantinha uma família na Bahia, e era a esposa e os filhos quem ia visitar quando se ausentava de Minaçu. Repetindo-se com ela algo semelhante ao que se passara com outras mulheres da cidade, Aparecida então se deu conta de algo que nunca mais esqueceu: homem do trecho não presta, mente muito... Durante a construção de Cana Brava, alguns anos depois, ela iniciou também um relacionamento com um homem de fora que trabalhava 
nas obras. Porém, já ciente dos riscos que corria, não deixou que a relação ficasse séria, nem criou maiores expectativas de algo duradouro. Ela sabia então que de uma hora para outra esse homem iria espalhar no mundo, e que o melhor era se precaver. E era justamente em função de sua experiência que ela se indignava com a forma como sua amiga e vizinha, Elenita, se portava. Como era possível agüentar aquela situação sem fazer nada? Ela, Aparecida, sabia que com um homem desses que rasga o trecho é preciso apertar a rédea: "Deixa de ser boba e vai exigir uma casa desse homem, ô Elenita!".

\section{O Trecho a favor da Família}

Quando se mudou para Brasília para estudar, Anderson - o jovem cuja volta para casa era festejada no almoço citado acima - foi dividir uma casa com uma conhecida da família. Seus pais diziam que náo fazia sentido ele ir morar com um de seus inúmeros tios ou tias que já estavam lá. "Sabe como é, parente cobra muito... 'Eu te fiz isso, eu te fiz aquilo'. E tudo acaba ficando mais fácil na casa deles, a responsabilidade diminui...”. O controle, a assistência, as obrigações recíprocas características dos vínculos familiares parecem assim ser considerados em alguma medida inadequados (ou apenas pouco recomendáveis) para aquele que vai encarar o trecho. Em especial para alguém que vai fazê-lo pela primeira vez, e contando com o apoio e a expectativa dos familiares que deixa para trás.

Já morando havia algum tempo em Brasília, Anderson certo dia me disse que tinha algo para confessar: "Quando eu era mais novo e brigava com meus pais por qualquer bobagem, eles diziam: 'um dia o trecho vai te ensinar...'. Eu nem ligava para aquilo, achava uma boba- gem. Mas hoje vejo como eles tinham razão! Sei hoje que o trecho bate, que a gente sofre, que a gente aprende. É isso o que vivo hoje em dia aqui na selva que é essa cidade, passando por tanto aperto... Não tenha dúvida disso: hoje que conheço melhor o que é o mundo, sou uma pessoa melhor, entendo e valorizo muito mais meus pais. Tenho até vergonha de como eu era antes. Hoje sou um filho muito melhor. Por meus pais, hoje eu faço qualquer coisa!”.

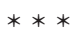

Sob certos aspectos, o trecho aparece como uma verdadeira ameaça à família, como motivo de inquietação e sofrimento para os pais, sempre temerosos de que seus filhos se percam por causa de drogas ou más companhias; de que sofram acidentes ou arrumem desavenças; de que sumam no mundo e não dêem mais notícias. Por outro lado, o que a experiência de Anderson em Brasília mostra é que o trecho não é encarado como algo intrinsecamente ruim ou pernicioso. Ele está associado a uma imprevisibilidade e perigos que constituem algo como o contraponto às dinâmicas e relações que vigoram no "domínio" do familiar (ou seja, do que se refere à família; e também do que é conhecido). Esta imprevisibilidade e estes perigos, porém, produzem também efeitos educativos. Nesse sentido, é de interesse da própria família que seus membros mais novos saiam de casa, enfrentem dificuldades e assim amadureçam. Bater para ensinar: não são somente os pais que fazem isso, mas também o próprio trecho, complementando assim a educação oferecida por eles.

Esta complementaridade está vinculada, entre outras coisas, a uma distinção na natureza dos vínculos que se estabelecem nestes dois domínios. O que parece marcar de modo diferencial a vida no trecho são relações estruturadas 
a partir de princípios distintos daquela "reciprocidade" emblemática do universo familiar. No limite, ao trecho se encontram associadas outras modalidades de troca. Nesse sentido, ele seria então o espaço por excelência (o que não quer dizer "exclusivo") de certas práticas que, em outros contextos, seriam mal vistas ou objeto de condenaçóes mais severas: a generosidade "potlatchiana" dos que "fecham cabarés" ou gastam todo seu salário em farras com amigos; a fuga de obrigaçóes e compromissos, particularmente os mais duradouros ("Engravidei a menina? Tá na hora de pegar descendo, de abrir no mundo..."); o apelo a transaçóes que não implicam na exigência de maiores retribuiçôes, como certas modalidades do pedir como o "se-me-dão" ("To fumando agora na base do se-me-dão [cigarros]!”); a malandragem dos que recorrem a pequenos golpes, "171 pra cá, 171 pra lá" ${ }^{\prime}$. É sugestivo, assim, que aqueles "peões do trecho" mencionados por Esterci (1985) sejam encarados como portadores dos signos da "desorganização social" - o que só reflete um ponto de vista bastante comum a respeito deles.

$\mathrm{O}$ aprendizado que um pai espera que seu filho obtenha no trecho não é - na maioria das vezes - o dessas práticas. Dentre outras coisas, o que ele pretende é sim que seu filho trave contato com o mundo, o universo onde elas proliferam, familiarizando-se e sabendo lidar com elas e com outras coisas, mais sérias e cruéis. E que o faça por sua própria conta, para que perceba que o tipo de relação e de vivência característicos da família são antes a exceção do que a regra - a vida "lá fora" é dura.

O trecho, assim, é o lócus por excelência do contato com o mundo, aquela "área" ou "universo" onde este último pode ser apreendido em toda a sua exuberância. Lógica e ontologicamente, o mundo é primeiro, é o que existe antes de mais nada. Enquanto fundamento da cosmologia que busquei esboçar em outro trabalho (Guedes 2011), ele remete a um turbilhão de movimentos marcados pelo rebuliço, pela instabilidade, pela incerteza, pela febre e pela agitação. Talvez por isso ele assuste e encante ao mesmo tempo, e com tanta intensidade. Conhecer ou encarar o mundo é cair na realidade, é encarar a vida; e é dar-se conta do que há de contingente, batalhado e provisório no lar e na família. É no mundo - longe de casa, no trecho - que o mundo - a vida, a realidadese revela em toda a sua plenitude. Este mundo é, assim, um "lugar" perigoso e traiçoeiro - mas também fascinante e repleto de possibilidades.

Desta forma, a segurança e a previsibilidade relativas da casa são o resultado de esforços que buscam justamente delimitar, neste mundo e pela domesticação de suas forças, espaços que oferecem alguma proteção e conforto. Estes esforços são capazes de criar, assim, enclaves ou áreas protegidas onde a periculosidade e inconstância das relaçóes e forças características deste mundo foram domadas em prol de certa estabilidade e previsibilidade; áreas onde é possível gozar, por exemplo, de coisas excepcionais, raras e preciosas como a mordomia.

\section{Conclusão}

\section{Minha vida é andar por esse país... \\ (Luiz Gonzaga, "Vida de Viajante”)}

Aquilo que poderíamos chamar de "idioma

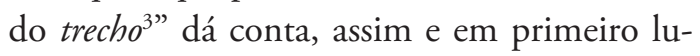
gar, das experiências associadas ao trabalho nos grandes projetos de desenvolvimento. Por outro lado, ele remete a uma concepção "tradicional" de como devem ser criados os filhos - pela reprodução de um modelo bastante antigo: não apenas Altino e Regina tocaram no mundo em sua 
juventude como também o fizeram seus respectivos pais. Estamos diante de "transformaçôes" associadas à modernização do interior do país ou de "continuidades" na "cultura sertaneja"?

As histórias de vida de muitos dos meus conhecidos de Minaçu (gente que está no mundo há mais de 30 anos) sugerem que transformaçôes significativas ocorreram por volta da década de 1970. Parece que foi nesse momento - que usualmente associamos às estratégias de integração nacional da ditadura militar e ao "desenvolvimentismo" daí decorrente -, quando os grandes projetos proliferaram e passaram a fazer parte da vida cotidiana de tantos, que o termo trecho surgiu. Neste sentido, aquela "vivência de projetos” de que fala Antonaz (1995, p. 56) poderia ser estendida para outros grupos além daqueles que nasceram e foram criados em vilas operárias: é justamente este o caso de meus interlocutores, cujas trajetórias estão marcadas por alternâncias e passagens por garimpos diversos (com freqüentes conflitos com mineradoras e, como no caso de Minaçu, com as empresas do setor elétrico); e pelo trabalho (temporário e não-qualificado) em barragens, na construção civil ou em grandes empreendimentos agropecuários.

Estas informações vão de encontro ao já citado comentário de Corrêa (2007) a respeito da origem do termo trecho e também aos dados presentes na literatura, e sinalizam que este trecho se vincula ao encontro desta nova realidade das grandes obras e projetos no centro-norte do país com uma já existente "tradição" de mobilidade popular. As referências ao trecho - assim como o fato de que o "idioma" a ele associado se constituiu via a apropriação e transformação de expressóes anteriormente vinculadas à categoria mundo - assinalariam assim as novas condiçóes e contextos com que se defrontariam os que se pusessem a andar pelo país; como se o surgimento e difusão do termo remetessem a uma nova feição do mundo, assinalando ao mesmo tempo uma ruptura (referente a estas transformaçóes sociais e econômicas dos anos 70) e uma continuidade (justamente com a experiência das geraçôes anteriores que já há muito tempo estão no andando por aí).

O trecho passou a ser, assim, a cara assumida pelo mundo nos canteiros de obras, usinas e alojamentos espalhados por todo o país. Mas não é somente isso, na medida em que, extrapolando estes espaços e situaçóes, retorna ao "mundo" mais amplo para, aí, vitalizar e re-significar toda uma tradição de mobilidade popular bastante antiga - o que, por exemplo, Vieira (2001) vai chamar de "cultura da andança" emblematicamente expressa por certos sentidos associados à categoria mundo . $^{4}$

As experiências dos atuais habitantes de Minaçu (e em especial daqueles pertencentes às camadas populares, grupo sob o qual reside meu foco) são reveladoras do papel desempenhado pelos deslocamentos em suas vidas. Nesta cidade, através de narrativas que muitas vezes assumiam tons épicos, fiquei sabendo como chegaram até ali os primeiros habitantes da região, vindos do Maranhão em busca de terras livres, no final dos anos 50; fiquei sabendo também da luta enfrentada por aqueles que, incapazes de obter um lote na Colônia Agrícola do Norte de Goiás, continuaram rumo ao norte, enfrentando grileiros e o próprio Estado, anos ou décadas depois finalmente se estabelecendo nas redondezas da cidade (dizimando, um pouco antes, alguns avá-canoeiros que ainda circulavam por ali); das desventuras das moças que foram trabalhar como faxineiras, dançarinas ou prostitutas na Espanha e na Suíça, após o fim do garimpo; dos que foram laçados no nordeste para trabalhar nas mineradoras; dos garimpeiros que afluíram em peso para Minaçu nos anos 80, vindos de Serra Pelada, Cumaru, Crixás, Uruaçu, dispersando-se novamente 
após a construção das barragens; dos que se espalharam e se perderam dos familiares no Mato Grosso, Pará ou Brasília; das andanças dos atingidos por todo o país, acampando e marchando pelo recebimento dos seus direitos; das peregrinaçóes e romarias até o Muquém ou Bom Jesus da Lapa, das histórias dos boiadeiros, dos caixeiros viajantes, dos caminhoneiros, dos calungas fugindo do cativeiro, da Coluna Prestes ou da família Caiado...

Na perspectiva nativa, essas diferentes situações apresentam um traço comum: elas são todas pensadas como formas de andar, rodar, estar no mundo (ou no trecho, dependendo de quem fala). O que pretendo sugerir com isso é a existência de uma "tradição" em que o deslocamento e a mobilidade são "coisas da vida"; algo que se espera e se imagina que faça parte da realidade de todas essas pessoas 5 . Como a discussão do caso de Anderson mostra, existe entre aqueles com quem convivi a expectativa de que, ao menos durante determinado período da vida, as dificuldades e vicissitudes do trecho sejam conhecidas e encaradas - para que alguém se torne mais maduro ou esperto, ou uma pessoa melhor.

Estamos longe, aqui, de certa visão que permeia a ideia de "migração" e que pressupóe que o deslocamento é fruto de acontecimentos singulares, implicando a saída de um ponto para outro (do campo para a cidade, ou dos nordestinos para o sudeste). A "sedentariedade" ou o "enraizamento" apareceriam aí como a regra, a situação "normal"; e o movimento como a exceção, o intersticial ou o acidental, algo secundário ou derivado em relação à estabilidade de quem fica no mesmo lugar. Do ponto de vista analítico, seria assim o movimento - e não a "permanência" - o que tem que ser explicado. Subordinado à "partida" e/ou ao "destino", o movimento não teria um valor em si mesmo, constituindo-se como a simples passagem entre dois pontos (Palmeira; Wagner, 1977), pontos onde residiria o interesse do pesquisador (por que sair? o que decorre do estar lá?). Para meus interlocutores, da mesma forma que estes pontos, o que está "entre" eles (o mundo, o trecho) também é "habitável".

O que estaria em jogo, assim, ao falarmos no trecho? Estamos diante de um constrangimento estrutural ou de um traço "cultural"? Tratamos dos impactos de um modelo econômico (excludente, eletro-intensivo, agro-minero-exportador, etc.) ou de uma tradição que remonta ao século XVIII, ou mesmo ao XVII?

Não pretendo minimizar as adversidades decorrentes da existência destes grandes projetos ou do modelo econômico a eles vinculado sobre a vida destas pessoas. Alguns minutos de conversa com qualquer um em Minaçu evidenciam o quanto as barragens trouxeram sofrimento e miséria para boa parte de sua população - mazelas articuladas, por muitos deles, ao "capitalismo" ou às "multinacionais". Dramas e dificuldades diversas se articulam também àqueles deslocamentos de um passado mais remoto, eles também remetendo às conseqüências da dominação, de um modelo de desenvolvimento ou coisa que o valha. Parece-me, porém, que seria um desrespeito às próprias concepçốes destas pessoas reduzir a sua mobilidade a estes fatores, como uma reação mecânica a injunções que lhes são impostas de fora. Talvez devêssemos, nesse contexto, acompanhar a sugestão de Sahlins (1997, p. 53) e considerar então a realidade dos "que souberam extrair, de uma sorte madrasta, suas (...) condições de existência”. Fazer da necessidade virtude: se somos deste sempre tocados como gado, postos a andar (pela seca, pelas barragens, pelas mineradoras, pela polícia, pelos podero- 
I 50 | ANDRÉ Dumans Guedes

sos, pelos grileiros), quem sabe se, imprimindo velocidade aos nossos passos e passando a correr, não nos tornamos leves e fugidios, cosmopolitas, versáteis, desembaraçados, astuciosos? Se rasgar no pé é um imperativo, que ao menos o confronto com o trecho seja também uma oportunidade de aprender alguma coisa; de se tornar maduro, experiente, vivido ou malandro; de ver e viver coisas novas, sobre as quais se falará pelo resto da vida, diante de ouvidos respeitosos e curiosos; de festar loucamente...

\section{On the road, tearing through the trecho: Popular Mobility, Family and Large Develop- ment Projects}

abstract In this paper I discuss some processes related to the "life on the trecho": expression used in the North of the Brazilian state of Goiás to describe the experiences of those people who work far away from their hometowns, as small scale miners or for companies related to large development projects. I present some of the implications of these experiences for family and sexual issues, trying to show how the discussion of these topics allows us to understand broader questions, related to central values and meanings of this universe. I also suggest that in these situations we are facing, at the same time, the persistence and transformation of traditional practices related to what we could call a "wandering culture", for a long time present in the hinterland of the country.

keywords Life on the road. Large development projects. Family. Mobility. Popular culture

\section{Notas}

1. Nos anos 80, foram os trabalhos de Marazzarollo (2003 [1980]), Sigaud (1988), Sigaud et al. (1987) e Grzybowski (1987) os precursores e inspiradores de pesquisas que se multiplicaram exponencialmente a partir da metade dos anos 90. Para uma revisão parcial da literatura existente, ver Magalhães (2007).

2. Categorias e elementos como esses evidenciam como a experiência dos "trecheiros" ("andarilhos", "pardais", "moradores de rua" etc. que circulam de uma cidade a outra no sul e sudeste do país, sem moradia fixa e levando consigo todos os seus pertencentes) está associada a uma "migração" e "transformação" dos elementos e categorias que discuto aqui. $\mathrm{O}$ vínculo entre estes dois contextos é evidenciado por uma série de outros aspectos, como o fato de muitos destes "trecheiros" terem trabalhado, antes de se entregarem ao seu nomadismo "não-ocupacional", como caminhoneiros, garimpeiros, vendedores ambulantes e peóes de obra (Mendes 2007, Araújo 2004). A literatura sobre este grupo já é relativamente grande, destacando-se aí o trabalho de Brognoli (1999). Ao que me parece, nenhum dos autores que trataram deste tópico relacionou estes trecheiros "do sul" ao trecho que eu considero aqui ("do norte", "do interior"). Qualquer procedimento comparativo nesse sentido é inegavelmente frutífero: e mais do que isso, reforça e complexifica a ideia de uma "tradição popular de mobilidade" (algo que tratarei logo abaixo) como vetor ou linha de força difusa que trespassa e se atualiza em situações as mais diversas, através de uma série de transformações tais quais as acima mencionadas.

3. O uso deste vocabulário se caracteriza por alguns traços que evidenciam a sua importância para as pessoas de que trato aqui: a) a freqüência com que ele é evocado; b) a solenidade que por vezes - mas não sempre - acompanha a sua utilizaçáo, como que a explicitar que o que está sendo dito não é algo trivial, demanda atenção e merece respeito; c) o luxuriante vocabulário disponível, a partir das noçóes "parentes" de trecho e mundo, para dar conta das modalidades de partida e das formas de "habitar" esse espaço não-familiar, em especial no que se refere a verbos ou locuções verbais que se articulam em torno da ideia de partida: espalhar no mundo, tirar para fora, bolar no mundo, sair no liso, escapulir, puxar a carreta, vazar, pegar descendo, rasgar no pé, rasgar no mundo, correr trecho, rodar o trecho, andar no trecho, espalhar no mundo, tocar no mundo, abrir no mundo, desgarrar do talo... Ver, a esse respeito, a extensa listagem de sinônimos e locuçóes populares associados aos verbetes "fugir" e "mundo" no Dicionário Aurélio. 
Abrir no Mundo, Rasgando o Trecho | I 5 I

4. Estudando grupos camponeses no nordeste - área de origem da maioria da população atual de Minaçu outros autores destacaram a importância da categoria mundo para dar conta das migraçóes que, longe de surgirem apenas como o resultado de necessidades de ordem socioeconômica, possuem também sua dimensão ritual e de formação da pessoa - sobretudo no que se refere aos homens. "Para tornar-se homem é preciso enfrentar o mundo (...) Os filhos de todas as categorias sociais devem 'conhecer o mundo'. Vários sitiantes referiam-se com evidente orgulho às suas viagens; aos lugares 'adiantados' que conheceram, cidades ou regióes agrícolas; à intimidade adquirida com implementos agrícolas modernos; a tipos de alimentação distintos daqueles habituais na região. Ter viajado torna as pessoas superiores a quem nunca saiu do lugar. A migração marca, sobretudo, a superioridade dos que agora são homens com relação aos que ainda são rapazes" (Woortmann, 2009, p. 219). O "meio do mundo", para Scott (2009, p. 266), aparece assim como um "espaço simbólico de uma liberdade que se apresenta a todos como uma maneira de aproveitar recursos em locais mais distantes", alternativa ao cativeiro do trabalho nas fazendas locais. Woortamnn (2009, p. 218) destaca, porém, as ambiguidades inerentes a esse termo: pois se para os camponeses nordestinos São Paulo aparece como "o mundo", tal cidade "não é apenas o lugar da riqueza”; mas também um espaço marcado pela "incerteza, o desconhecido, o perigo".

5. Certamente não estou sendo original aqui. Essa ideia se faz presente - com especial destaque para o que diz respeito ao "homem pobre do interior" - numa série de textos clássicos do pensamento social brasileiro (dentro tantos outros, podemos citar Gilberto Freyre, Maria Sylvia de Carvalho Franco, Sérgio Buarque de Holanda, Caio Prado Jr., Laura de Mello e Souza, Antônio Cândido e Vianna Moog). Velho (1979, p. 236), destacando a importância do "reconhecimento dos limites de nossas análises socioeconômicas” dos deslocamentos espaciais, menciona "um fenômeno que tem intrigado os estudiosos há muito tempo (...) certa tendência prevalecente entre os brasileiros das camadas inferiores a uma constante e aparentemente inexplicável migração que já levou em outros tempos à suposição de um 'instinto migratório atávico' herdado dos índios", e que poderia ser talvez explicado, segundo ele, pelo temor de que estes "migrantes" fossem "apanhados e postos no cativeiro". Sobre esta tensa e complexa relação entre o mundo e o cativeiro, ver Scott (2009) e Guedes (2011).

\section{Referências bibliográficas}

ANTONAZ, Diana. Na Escola dos Grandes Projetos. A Formação do Trabalhador Industrial na Amazônia. Dissertação de Mestrado em Antropologia Social Programa de Pós-Graduação em Antropologia Social, Universidade Federal do Rio de Janeiro, 1995.

ARAUJO, Wânia Maria. População de Rua de BH: Reinvenção de Espaços Domésticos no Improviso da Moradia. Dissertação de Mestrado em Ciências Sociais, Programa de Pós-Graduação em Ciências Sociais, Pontifícia Universidade Católica, Belo Horizonte, 2004.

BROGNOLI, Felipe. Com a Cara no Mundo: Seguindo os Rastros de Nômades Urbanos. In MARQUES, A.C.; VILELLA, J. BROGNOLI, F. (Orgs). Andarilhos e Cangaceiros: A Arte de Produzir Territórios em Movimento. Itajaí: Ed. da Univalli. 1999

BUARQUE DE HOLANDA, Sérgio. Caminhos e Fronteiras. São Paulo: Companhia das Letras, 1994.

CORRÊA, Orlando J. D. Urrando no Trecho. Recordaçôes de um Engenheiro de Obras. Rio de Janeiro: Editora Corifeu, 2007.

COSTA, Patrícia Trindade. A Construção da Masculinidade e a Banalidade do Mal: Outros Aspectos do Trabalho Escravo Contemporâneo. Cadernos Pagu, n. 31, p. 173-198, 2008.

ESTERCI, Neide. Conflito no Araguaia. Peóes e Posseiros contra a Grande Empresa. Tese de Doutorado em Ciências Sociais - Faculdade de Filosofia, Letras e Ciências Humans, Universidade de São Paulo, 1985. FIGUEIRA, Ricardo Rezende. Pisando Fora da Própria Sombra. A Escravidão por Dívida no Brasil Contemporâneo. Rio de Janeiro: Civilização Brasileira, 2004.

GRZYBOWKSI, Cândido. Caminhos e Descaminhos dos Movimentos Sociais no Campo. Petrópolis: Vozes, 1987.

GUEDES, André Dumans. O Trecho, As Mães e os Papéis. Movimentos e Duraçôes no Norte de Goiás. Tese de Doutorado em Antropologia Social - Programa de Pós-Graduação em Antropologia Social, Universidade Federal do Rio de Janeiro, 2011.

MAGALHÃES, Sonia Barbosa. Gente de Toda Paragem. Um Estudo sobre a Populaçáo Afluente numa Grande Obra. Dissertação de Mestrado em Ciências Sociais - Faculdade de Filosofia e Ciências Humanas, Universidade Federal da Bahia, 1983.

MARTINS, José de Souza. Migraçóes temporárias. Problema Para Quem? Revista Travessia, n. 1, p. 5-8, 1988. 
I 52 | ANDRÉ Dumans Guedes

MAUSS, Marcel. Ensaio sobre a Dádiva. Forma e Razão da Troca nas Sociedades Arcaicas. In: . Sociologia e Antropologia. São Paulo: Edusp, 1974. p. 49-67. MAZZAROLLO, Juvêncio. A Taipa da Injustiça. Esbanjamento Econômico, Drama Social e Holocausto Ecológico em Itaipu. São Paulo: CPT/Ediçóes Loyola, 2003.

MENDES, Mariana Villas Boas. Os moradores de rua e suas trajetórias. Dissertação de Mestrado em Sociologia - Faculdade de Filosofia e Ciências Humanas, Universidade Federal de Minas Gerais, 2007.

PALMEIRA, Moacir; WAGNER, Alfredo. A Invenção da Migração. Relatório de Pesquisa. Projeto Emprego e Mudança Sócio-Econômica no Nordeste. Programa de Pós-Graduação em Antropologia Social, Universidade Federal do Rio de Janeiro, 1977.

RUMSTAIN, Ariana. Peóes no Trecho. Estratégias de Trabalho e Deslocamento no Mato Grosso. Dissertação de Mestrado em Antropologia Social - Programa de Pós-Graduação em Antropologia Social, Universidade Federal do Rio de Janeiro, 2009.

SAHLINS, Marshal. O "Pessimismo Sentimental". Por que a Cultura Não é um "Objeto” em Via de Extinção. Mana, v. 3, n.1, p. 41-73, 1997.

SCOTT, Russel Parry. Famílias Camponesas, Migraçóes e Contextos de Poder no Nordeste: entre o "Cativeiro" e o "Meio do Mundo". In: GODOI, E. P.; MENEZES, M.A.; MARIN, R. (Orgs.). Diversidade do Campesinato: Expressões e Categorias, v.2: Estratégias de Reprodução Social. São Paulo: Editora UNESP, 2009. p. $245-268$.
SIGAUD, Lygia, MARTINS-COSTA, Ana Luiza e DAOU, Ana Maria. Expropriação do Campesionato e Concentração de Terras em Sobradinho: uma Contribuição à Análise dos Efeitos da Política Energética do Estado. In: Ciências Sociais Hoje. São Paulo: Vértice/ Anpocs, 1987.

SIGAUD, Lygia. Efeitos Sociais de Grandes Projetos Hidrelétricos: as Barragens de Sobradinho e Machadinho. In: PINGUELLI, Luiz (Org.). Impactos de Grandes Projetos Hidrelétricos e Nucleares. Aspectos Econômicos, Tecnológicos, Sociais e Ambientais. Rio de Janeiro: UFRJ/COPPE, 1988.

SOUZA, Ângela. As Políticas de Gestão da Força de Trabalho e as Condiçóes de Vida do Trabalhador das Obras Barrageiras. Revista Travessia, n. 6, p. 25-32, 1990.

VELHO, Otávio. Capitalismo Autoritário e Campesinato. São Paulo: Difel, 1979.

VIEIRA, Maria Antonieta da Costa. À Procura das Bandeiras Verdes. Viagem, Missão e Romaria. Movimentos Sócio-Religiosos na Amazônia Oriental. Tese de Doutorado em Antropologia Social - Instituto de Filosofia e Ciências Humanas, Universidade Estadual de Campinas, 2001.

WOORTMANN, Klaas. Migração, Família e Campesinato. In: WELCH, C.(Org.). Camponeses Brasileiros: Leituras e Interpretaçóes Clássicas, v.1. São Paulo: Editora UNESP, 2009.

\section{autor André Dumans Guedes}

Doutor em Antropologia Social / PPGAS - Museu Nacional

Recebido em 22/03/2012

Aceito para publicação em 01/10/2012 